\title{
MORPHOLOGICAL, TEXTURAL AND THERMAL PROPERTIES OF LOW-COST SILICA AEROGEL COMPOSITES
}

\author{
${ }^{1}$ Gülcihan GÜZEL KAYA (D) , ${ }^{2}$ Hüseyin DEVECi $(D)$ \\ Konya Technical University, Engineering and Natural Sciences Faculty, Chemical Engineering Department, \\ Konya, TURKEY \\ 1'ggkaya@ktun.edu.tr, ${ }^{2}$ hdeveci@ktun.edu.tr
}

(Geliş/Received: 10.07.2021; Kabul/Accepted in Revised Form: 13.08.2021)

\begin{abstract}
Nowadays, silica aerogels with promising properties have gained interest in many fields. To enhance properties of the silica aerogels and reduce material cost, many approaches such as preparation of silica aerogels composites using low-cost precursors rich in silica have been developed. In this study, polyethylene glycol (PEG)/silica and carbon black (CB)/silica aerogel composites were easily prepared by sol-gel method. Morphological properties of the composites were investigated by field emission scanning electron microscopy (FESEM) analysis. PEG and CB incorporation improved textural properties of the silica aerogel. Specific surface area of the silica aerogel was increased from $477 \mathrm{~m}^{2} / \mathrm{g}$ to $541 \mathrm{~m}^{2} / \mathrm{g}$ and $553 \mathrm{~m}^{2} / \mathrm{g}$ with the addition of PEG and CB, respectively. Moreover, silica aerogel composites showed higher pore volume and pore size than silica aerogel. It was determined that $\mathrm{CB} /$ silica aerogel composite exhibited the highest thermal stability. Thermal conductivity of the silica aerogel $(0.035 \mathrm{~W} / \mathrm{m} \mathrm{K})$ slightly increased with PEG and CB addition highly depending on bulk density. The bulk density of PEG/silica and CB/silica aerogel composites was specified as $0.048 \mathrm{~g} / \mathrm{cm}^{3}$ and 0.067 $\mathrm{g} / \mathrm{cm}^{3}$, respectively. The obtained results showed that silica aerogel composites with hopeful properties can be used in many applications.
\end{abstract}

Key Words: Silica aerogel, Composite material, Morphological properties, Textural properties, Thermal properties

\section{Düşük Maliyetli Silika Aerojel Kompozitlerin Morfolojik, Yapısal ve Termal Özellikleri}

ÖZ: Silika aerojeller günümüzde umut vadeden özellikleriyle birçok alanda ilgi görmektedir. Silika aerojellerin özelliklerini geliştirmek ve malzeme maliyetini azaltmak amacıyla yüksek oranda silika içeren ucuz malzemelerden silika aerojel kompozitlerin hazırlanması gibi yaklaşımlar geliştirilmektedir. Bu çalışmada sol-jel metodu kullanılarak polietilen glikol (PEG)/silika ve karbon siyahı (CB)/silika aerojel kompozitler kolayca hazırlanmıştır. Kompozitlerin morfolojik özellikleri alan emisyonlu taramalı elektron mikroskobu (FESEM) analizi ile incelenmiştir. PEG ve CB ilavesinin, silika aerojelin yapısal özellikleri üzerinde olumlu etkileri olmuştur. PEG ve CB ilavesiyle silika aerojelin spesifik yüzey alanı $477 \mathrm{~m}^{2} / \mathrm{g}^{\prime}$ den sırasıyla $541 \mathrm{~m}^{2} / \mathrm{g}$ ve $553 \mathrm{~m}^{2} / \mathrm{g}^{\prime}$ ye artmıştır. Ayrıca silika aerojel kompozitler, silika aerojelden daha yüksek gözenek hacmi ve gözenek boyutu göstermiştir. En yüksek termal kararlığ 1 $\mathrm{CB} /$ silika aerojel kompozitin gösterdiği belirlenmiştir. Malzemelerin yoğunluğuna bağlı olarak PEG ve CB ilavesiyle silika aerojelin termal iletkenliği $(0.035 \mathrm{~W} / \mathrm{m} \mathrm{K})$ kısmen artmıştır. PEG/silika ve CB/silika aerojel kompozitlerin yoğunluğu sırasıyla $0.048 \mathrm{~g} / \mathrm{cm}^{3}$ ve $0.067 \mathrm{~g} / \mathrm{cm}^{3}$ olarak belirlenmiştir. Elde edilen sonuçlar silika aerojel kompozitlerin sahip oldukları olumlu özellikleri sayesinde birçok uygulamada kullanılabileceğini göstermiştir. 


\section{INTRODUCTION}

Silica aerogels are porous materials which have interconnected structure with air filled pores (Talebi et al., 2019). Silica aerogels exhibit many unique properties such as porous structure, low density, high thermal resistance, low thermal conductivity, and so on (Liu et al., 2016; Nazeran and Moghaddas, 2017). These advantages make silica aerogels potential materials in various fields including thermal and acoustic insulation, automotive, electronics, sensors, gas capture and liquid adsorption/absorption processes, catalysts, and biomedical applications (Iswar et al., 2017; Maleki et al., 2016; Pisal and Rao, 2016; Wu et al., 2012). However, their poor mechanical strength, brittleness, hydrophilicity, and highcost restrict their utilization in large-scale applications (Choi et al., 2020; Rezaei et al., 2020).

Silica aerogel composites have been prepared by the combination of silica aerogel and different types of additives (metals, metal oxides, polymers, carbon-based materials, and porogen materials) to improve current properties of silica aerogels or gain new properties to silica aerogels (Acosta-Rangel et al., 2018; Gurav et al., 2010). For example, some metals like Fe and La increase specific surface area of silica aerogels leading to higher efficiency in adsorption and photocatalytic processes (HernandezCampos et al., 2018). Usage of Ag, Au and Pd enhances chemical stability of silica aerogels that provides many advantages in optical and biomedical applications (Krylova et al., 2009). To change electrical, optical, magnetic and catalytic properties of silica aerogels, metal oxides $\left(\mathrm{TiO}_{2}, \mathrm{Fe}_{2} \mathrm{O}_{3}, \mathrm{NiO}, \mathrm{ZnO}\right.$, etc. $)$ are commonly used (Casula et al., 2011; Mo et al., 1998; Popovici et al., 2004; Zhu et al., 2009). Mechanical properties of silica aerogels are improved with the addition of thermoplastic/thermoset polymers such as epoxy, polystyrene, polyester, nylon-6, and so on (Abdul Halim et al., 2017; Ge et al., 2009; Ilhan et al., 2006; Krishnaswamy et al., 2017). Carbon-based materials (carbon nanotube, graphene oxide and carbon black) significantly affect optical properties of silica aerogels (Zhao et al., 2013). Porogen materials including polyvinyl alcohol and glycerol have synergistic effects on the porous structure of silica aerogels. Silica aerogel composites with high surface area and controllable pore size are obtained using these materials (Durães et al., 2015; Kim et al., 2015).

Silica aerogel composites can be easily prepared the by sol-gel method which consists of gelation, aging and drying steps. Additives can be added into silica sol before gelation or diffused/adsorbed to silica gel before drying step (Sachithanadam and Chandrakant Joshi, 2016). In the formation of silica sol, conventional silicon alkoxides which are expensive and hazardous chemicals are generally preferred (Zinzi et al., 2019). However, recently, inorganic/organic waste and industrial by-products have been used as silica precursor that reduces material cost as well as waste accumulation leading to prevent environmental pollution (Guzel Kaya and Deveci, 2020a; Nazriati et al., 2014). In the formation of silica sol from these low-cost materials rich in silica, sodium silicate solution is first obtained by the alkali extraction method. Gelation is initiated with the addition of acid to the sodium silicate solution at optimum pH value (Affandi et al., 2009; Guzel Kaya et al., 2020; Shi et al., 2010). The gel is strengthened in different types of solvents such as alcohols, acetone, water, and ionic liquids. In the presence of solvents with low vapor pressure, highly porous silica aerogel network can be synthesized owing to a decrease in shrinkage of the silica gel (Aegerter et al., 2011). In the last step, solvents or water in the gel structure are removed by supercritical drying (Guzel Kaya and Deveci, 2020b). Supercritical drying is an effective method in which no liquid-vapor interface is observed. This method provides the preservation of the pore structure of the material with decreasing capillary stresses. $\mathrm{CO}_{2}$, which has low critical temperature, is widely used as a solvent in supercritical drying process (Aravind et al., 2010; Goksu et al., 2010).

Volcanic tuff, which is a low-cost material rich in silica (71.5\%), was utilized as a silica precursor in this work. With the addition of polyethylene glycol (PEG) and carbon black (CB) into the silica sol before gelation, composites were prepared. The effects of PEG and CB addition on the surface morphology, porous structure and thermal behaviour of the silica aerogel were investigated. The properties of the composites were compared with those of the neat silica aerogel and literature studies. 


\section{MATERIALS AND METHOD}

\subsection{Materials}

Volcanic tuff $\left(14.0 \% \mathrm{Al}_{2} \mathrm{O}_{3}, 71.5 \% \mathrm{SiO}_{2}, 4.2 \% \mathrm{~K}_{2} \mathrm{O}, 4.8 \% \mathrm{Na}_{2} \mathrm{O}, 1.3 \% \mathrm{CaO}, 2.8 \% \mathrm{Fe}_{2} \mathrm{O}_{3}, 0.5 \% \mathrm{MgO}, 0.5 \%\right.$ $\mathrm{TiO}_{2}, 0.1 \% \mathrm{MnO}$ and $\left.0.3 \% \mathrm{P}_{2} \mathrm{O}_{5}\right)$ was supplied from Kayseri Region, Turkey. $\mathrm{NaOH}(\geq 97 \%)$ and $\mathrm{HCl}$ (37\%) were purchased from Sigma-Aldrich. Isopropanol ( $\geq 99.8 \%$, Merck) and $n$-hexane (98.5\%, Merck) were obtained as aging and washing solvents, respectively. PEG-400 (Merck) and CB (particle size < 45 $\mu \mathrm{m}$ ) were evaluated as additives in the preparation of silica aerogel composites. All chemicals were used without further purification. In the solution preparation and aging step, distilled water was used.

\subsection{Preparation of silica aerogel composites}

Synthesis of silica aerogel was conducted using the sol-gel method as shown in Figure 1. Firstly, acid treatment was applied to remove impurities from volcanic tuff through mixing volcanic tuff and 3 $\mathrm{M} \mathrm{HCl}$ at $60{ }^{\circ} \mathrm{C}$ for $1.5 \mathrm{~h}$. The tuff was washed with water, and then dried at $70{ }^{\circ} \mathrm{C}$. After the extraction process in which the tuff and $3 \mathrm{M} \mathrm{NaOH}$ were mixed under the reflux for $5 \mathrm{~h}$, obtained $\mathrm{Na}_{2} \mathrm{SiO}_{3}$ solution was filtered. Gelation was initiated with adding $3 \mathrm{M} \mathrm{HCl}$ solution to $\mathrm{Na}_{2} \mathrm{SiO}_{3}$ solution and formation of silica gel was observed at about $\mathrm{pH} 10$. The gel was aged in the mixture of isopropanol/water (equal volume) at $50{ }^{\circ} \mathrm{C}$ for 1 day following the aging in isopropanol in the same conditions. To remove impurities and solvent from the silica gel, the gel was washed with $n$-hexane. Lastly, solvents or water were removed from the gel by $\mathrm{CO}_{2}$ supercritical drying (in two steps: (1) $100 \mathrm{bar}, 50{ }^{\circ} \mathrm{C}, 1.5 \mathrm{~L} / \mathrm{min} \mathrm{CO}_{2}$, $30 \mathrm{~min}$ and (2) $100 \mathrm{bar}, 50^{\circ} \mathrm{C}, 3.0 \mathrm{~L} / \mathrm{min} \mathrm{CO}_{2}, 2 \mathrm{~h}$ ).

In the preparation of silica aerogel composites, same procedure was performed (Figure 1). With the addition of PEG or $\mathrm{CB}$ to the $\mathrm{Na}_{2} \mathrm{SiO}_{3}$ solution before gelation, silica aerogel composites were obtained. PEG/silica and CB/silica aerogel composites were prepared using $10 \mathrm{wt} \%$ PEG and $0.33 \mathrm{wt} \% \mathrm{CB}$, respectively.

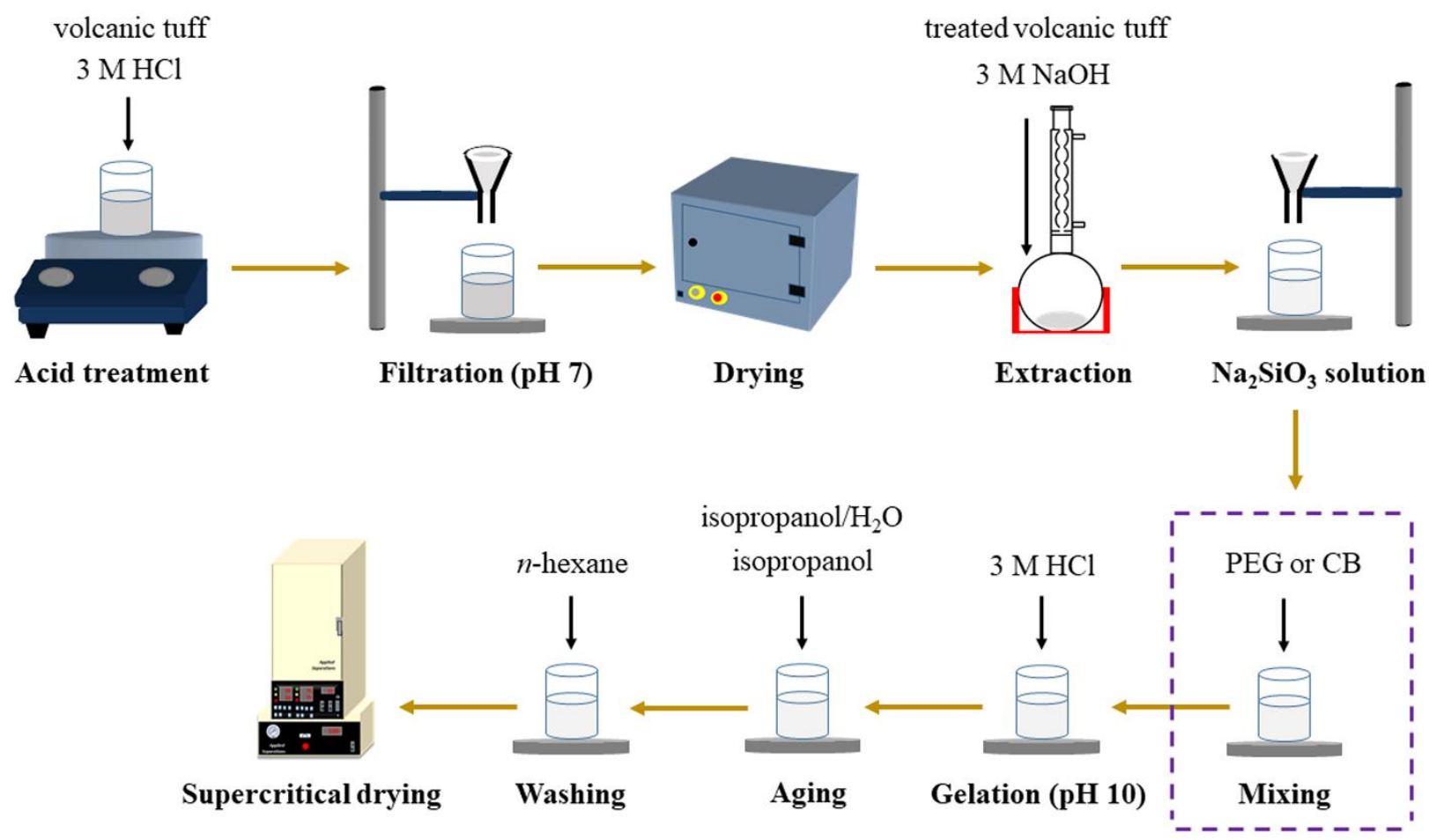

Figure 1. Preparation procedure of silica aerogel composites 


\subsection{Characterization of silica aerogel composites}

$\mathrm{X}$-ray diffraction (XRD) patterns of the samples were obtained using X-ray diffractometer (Bruker D8 Advanced, $40 \mathrm{kV}, 40 \mathrm{~mA}, \mathrm{Cu} \mathrm{K} \alpha$ radiation). Fourier transform infrared (FT-IR) data was collected to analyze chemical bonds of the samples by FT-IR spectrometer (Bruker Vertex 70). $\mathrm{N}_{2}$ adsorptiondesorption measurements were conducted to examine textural properties of the samples by Micromeritics Tristar II 3020 analyzer. Numerical values were calculated from the isotherm data with Brunauer-Emmett-Teller (BET) and Barrett-Joyner-Halende (BJH) methods. Morphological characterization of the samples was conducted by field emission scanning electron microscopy (FESEM) analyses (TESCAN MAIA3 XMU). Thermogravimetric analyses (TGA) were carried out using thermal analyzer (METTLER STAR SW, $\mathrm{N}_{2}$ atmosphere (flow rate of $30 \mathrm{~mL} / \mathrm{min}$ ), heating rate of $10^{\circ} \mathrm{C} / \mathrm{min}$ ). Thermal conductivity of the samples was determined using C-THERM thermal conductivity analyzer and average value was calculated through five times repeated measurements. Bulk density of the samples was recorded as mass of sample divided by volume.

\section{RESULTS AND DISCUSSION}

XRD patterns of the samples are shown in Figure 2a. The peak $\left(2 \theta=\sim 22^{\circ}\right)$ indicated preparation of amorphous materials (Jaiboon et al., 2014). There was no peak belonging to any impurities or $\mathrm{NaCl}$ owing to advantages of supercritical drying process. It is known that $\mathrm{Na}^{+}$ions in the material pores cause surface tension resulting in shrinkage of the materials (Hu et al., 2016). However, $\mathrm{Na}^{+}$ions were easily removed from the sample pores by preventing pore collapse related to surface tension in this study.
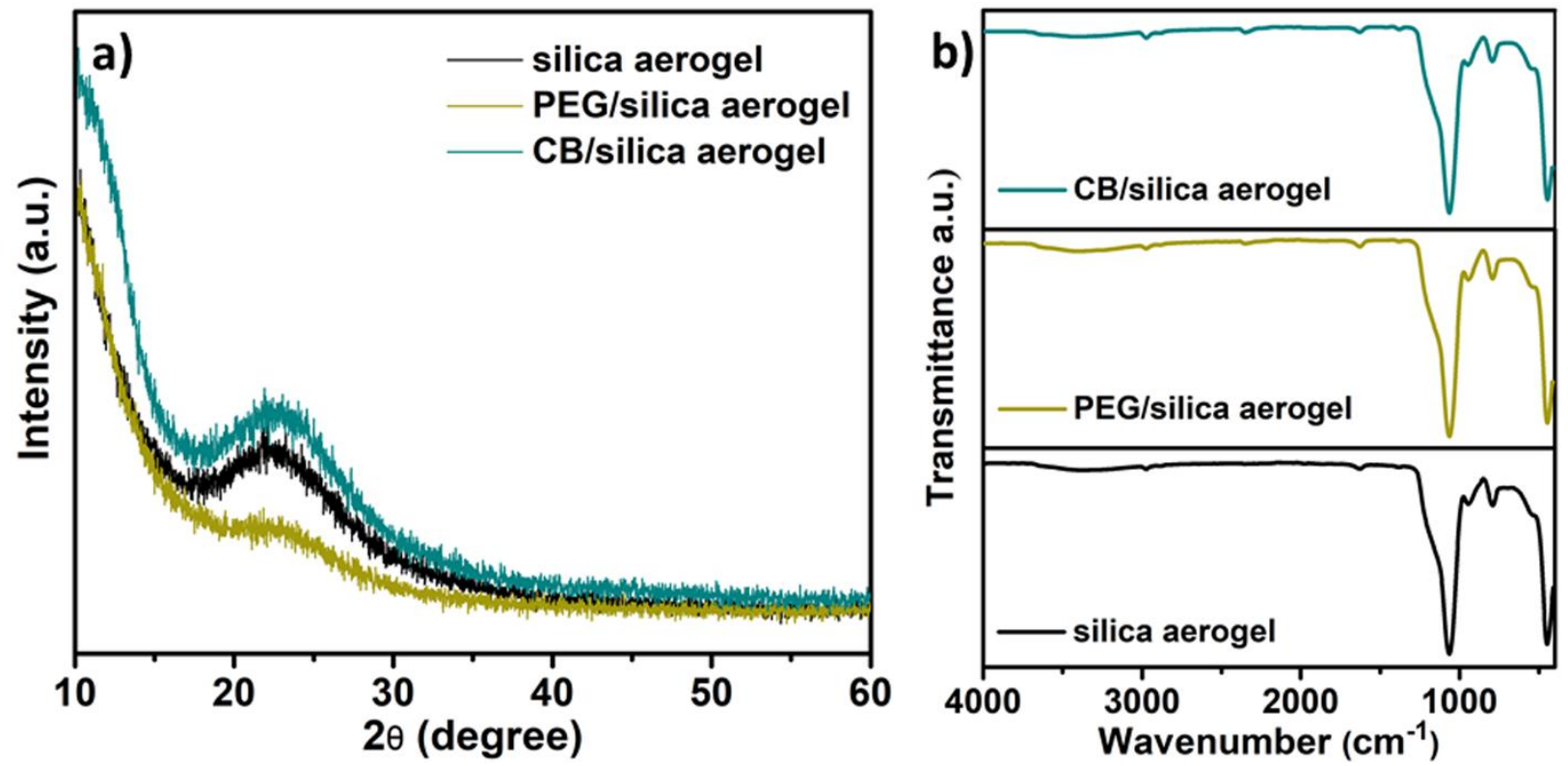

Figure 2. a) XRD patterns and b) FT-IR spectra of the samples

FT-IR spectra of the samples are shown in Figure 2b. It was obvious that the silica aerogel and its composites were successfully prepared from the tuff. The peaks belonging to characteristic Si-O-Si symmetric and asymmetric stretching vibrations of the silica aerogel were specified at $790 \mathrm{~cm}^{-1}$ and 1070 $\mathrm{cm}^{-1}$, respectively. At $450 \mathrm{~cm}^{-1}$, the peak contributed to Si-O-Si bending vibrations was observed (AlOweini and El-Rassy, 2009). The peaks with low intensity at $670 \mathrm{~cm}^{-1}$ and $940 \mathrm{~cm}^{-1}$ were attributed to Si$\mathrm{OH}$ stretching vibrations (Liu et al., 2020). The band centered at $3400 \mathrm{~cm}^{-1}$ indicated $-\mathrm{OH}$ stretching vibrations. Moreover, the peak related to water molecules on the material surface appeared at $1632 \mathrm{~cm}^{-1}$ (Zhang et al., 2017). 
There was no significant effect of PEG or CB addition on the FT-IR spectrum of the silica aerogel depending on low amount of additives. The peak C-O-C bonds of PEG molecules at $1100 \mathrm{~cm}^{-1} \mathrm{could}_{\mathrm{l}} \mathrm{not}$ be stated due to the high intensity of peak at $1070 \mathrm{~cm}^{-1}$ (Durães et al., 2015). The intensity of the band at about $3400 \mathrm{~cm}^{-1}$ increased slightly which can be explained with -OH groups of PEG in the FT-IR spectrum of PEG/silica aerogel composite. However, CB addition slightly decreased the intensity of the band.

$\mathrm{N}_{2}$ adsorption-desorption isotherms of the samples are shown in Figure 3 and related results are given in Table 1. The silica aerogel and silica aerogel composites presented type IV isotherm that indicates formation of mesoporous materials (Alothman, 2012). Moreover, the materials are defined as microporous materials $(<2 \mathrm{~nm}$ ), mesoporous materials (between $2 \mathrm{~nm}$ and $50 \mathrm{~nm}$ ), and macroporous materials (> $50 \mathrm{~nm}$ ) depending on pore size (Perego and Millini, 2013). It can be said that the samples obtained in this study were mesoporous materials.
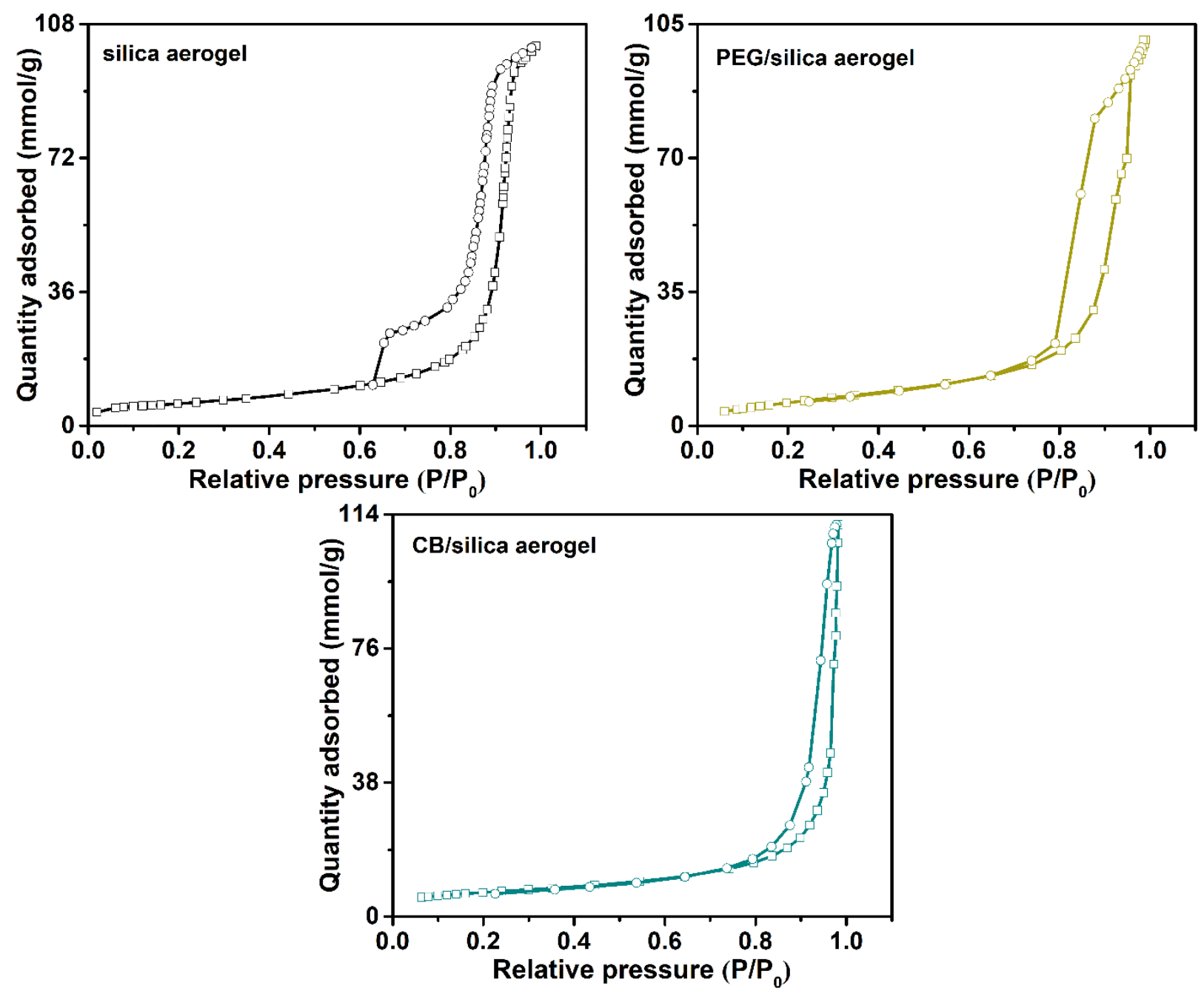

Figure 3. $\mathrm{N}_{2}$ adsorption-desorption isotherms of the samples

The specific surface area of the silica aerogel was specified as $477 \mathrm{~m}^{2} / \mathrm{g}$. PEG and CB incorporation into the silica network provided synergistic effects on textural properties of the silica aerogel. The specific surface area of PEG/silica and CB/silica aerogel composite was determined as $541 \mathrm{~m}^{2} / \mathrm{g}$ and 553 $\mathrm{m}^{2} / \mathrm{g}$, respectively. When compared to literature studies as given Table 2 , the silica aerogel composites prepared from volcanic tuff exhibited higher specific surface area than that of the some conventional silicon alkoxides and other materials rich in silica. The pore volume and pore size of the silica aerogel were considerably increased with the addition of PEG and CB. It is known that optimum amount of 
porogen materials can increase surface area of the materials and change pore structure.

Table 1. Textural and physical properties of the samples

\begin{tabular}{llll}
\hline Properties & silica aerogel & PEG/silica aerogel & CB/silica aerogel \\
\hline Specific surface area $\left(\mathrm{m}^{2} / \mathrm{g}\right)$ & 477 & 541 & 553 \\
Average pore size $(\mathrm{nm})$ & 19 & 21 & 24 \\
Pore volume $\left(\mathrm{cm}^{3} / \mathrm{g}\right)$ & 2.76 & 2.81 & 3.33 \\
Bulk density $\left(\mathrm{g} / \mathrm{cm}^{3}\right)$ & 0.036 & 0.048 & 0.067 \\
Thermal conductivity $(\mathrm{W} / \mathrm{m} \mathrm{K})$ & 0.035 & 0.041 & 0.043 \\
\hline
\end{tabular}

Table 2. Textural properties of silica aerogels synthesized from different precursors in literature studies

\begin{tabular}{lccc}
\hline Precursor & $\begin{array}{c}\text { Specific surface } \\
\text { area }\left(\mathrm{m}^{2} / \mathrm{g}\right)\end{array}$ & $\begin{array}{c}\text { Average pore } \\
\text { Size }(\mathrm{nm})\end{array}$ & $\begin{array}{c}\text { Pore volume } \\
\left(\mathrm{cm}^{3} / \mathrm{g}\right)\end{array}$ \\
\hline Wheat starch (Ubeyitogullari and Ciftci, 2016) & 59 & 22.0 & 0.24 \\
Bagasse ash (Nazriati et al., 2014) & 441 & 3.8 & 0.75 \\
Rice hull ash (Li and Wang, 2008) & 499 & 26.5 & 3.31 \\
Fly ash (Shi et al., 2010) & 362 & 10.4 & 0.95 \\
Kaolin (Hu et al., 2016) & 465 & 20.0 & 2.70 \\
Oil shale ash (Gao et al., 2010b) & 789 & 14.1 & 2.77 \\
Methyltrimethoxysilane (Durães et al., 2012) & 232 & 37.0 & - \\
\hline
\end{tabular}

FESEM images of the samples are shown in Figure 4. Silica aerogel composites presented similar surface morphology with the silica aerogel. It was obvious that the samples had interconnected structure including pores. PEG/silica and $\mathrm{CB} /$ silica aerogel composites exhibited more porous structure when compared to the neat silica aerogel, which was supported with $\mathrm{N}_{2}$ adsorption-desorption isotherms. Furthermore, in the presence of PEG and CB, more homogeneous dispersion of particles was observed.
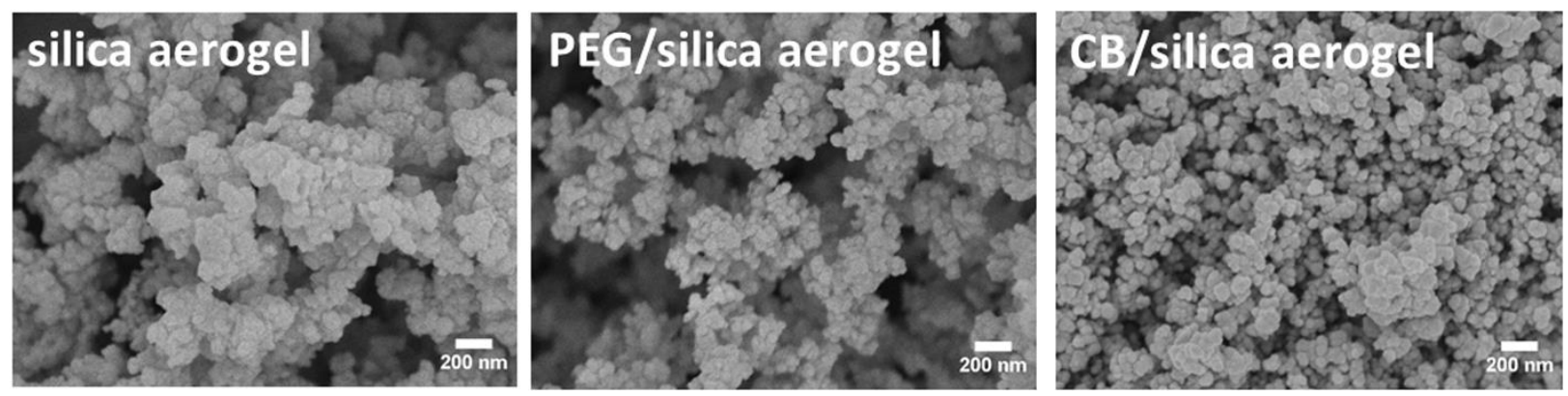

Figure 4. FESEM images of the samples

TGA curves of the samples are shown in Figure 5. Thermal decomposition of the samples occurred in three steps. Initially, removal of water molecules and solvents from the materials resulted in mass loss. Organics belonged to silica network started to decompose in the second step $\left(200-600{ }^{\circ} \mathrm{C}\right)$. At high temperatures, the samples preserved most of the residual mass. The residue of the silica aerogel at 800 ${ }^{\circ} \mathrm{C}$ was approximately $87 \%$ that indicated high thermal stability of the sample. Higher mass loss was determined in the presence of PEG, which can be attributed to lower decomposition temperature of PEG molecules (Suchithra et al., 2012). In contrast to PEG, CB incorporation into the silica network increased thermal stability of the silica aerogel depending on high thermal stability of the CB particles. 


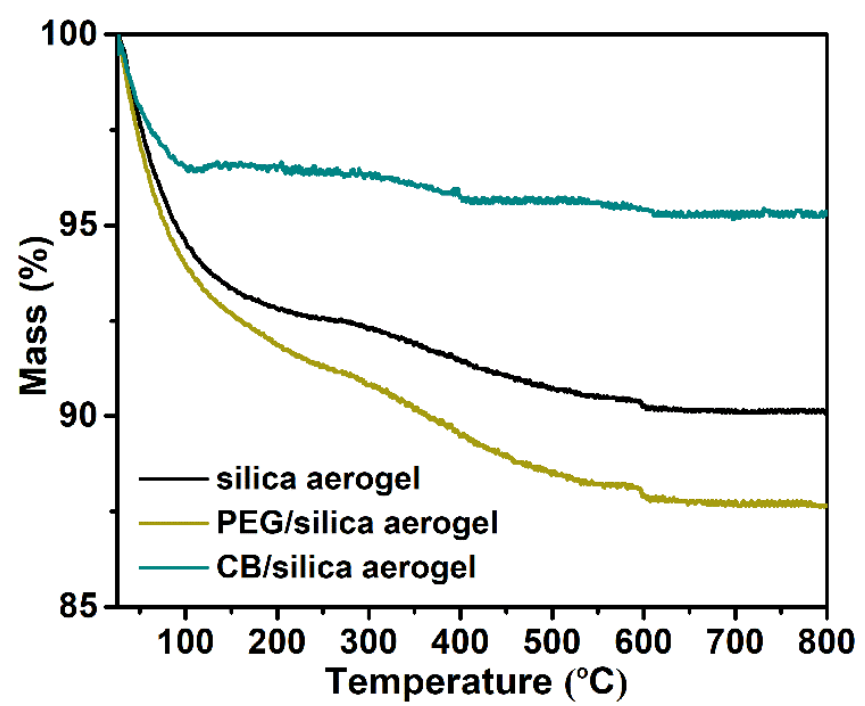

Figure 5. TGA curves of the samples

Thermal conductivity of amorphous materials is very low due to the phonon scattering resulted from disorder in atomic structure of the materials. And also, porosity of the materials significantly affects their thermal conductivity. High porosity generally decreases thermal conductivity of the materials with restricting heat conduction through the material (Lei et al., 2017a; Lei et al., 2017b). Moreover, thermal conductivity of the materials is directly associated with their bulk density. It is known that materials with low density decrease thermal conductivity. It can be explained with less solid content of the materials that makes difficult heat conduction (Jain et al., 2002). In this study, the silica aerogel had considerably low thermal conductivity $(0.035 \mathrm{~W} / \mathrm{m} \mathrm{K})$ as shown in Table 1 . With the addition of PEG and CB, thermal conductivity of the silica aerogel slightly increased. In spite of formation of silica aerogel composites with high pore volume, slight increase in thermal conductivity was observed depending on higher bulk density of the composites. The bulk density of PEG/silica and $\mathrm{CB} /$ silica aerogel composite was determined as $0.048 \mathrm{~g} / \mathrm{cm}^{3}$ and $0.067 \mathrm{~g} / \mathrm{cm}^{3}$, respectively. Although silica aerogel composites presented higher bulk density than silica aerogel, the samples still are better when compared to silica aerogels in literature studies (from wheat starch $\left(0.29 \mathrm{~g} / \mathrm{cm}^{3}\right)$, rice hull ash $(0.33$ $\left.\mathrm{g} / \mathrm{cm}^{3}\right)$, oil shale ash $\left(0.077 \mathrm{~g} / \mathrm{cm}^{3}\right)$, sodium silicate $\left(0.084 \mathrm{~g} / \mathrm{cm}^{3}\right)$, tetraethylorthosilicate $\left(0.097 \mathrm{~g} / \mathrm{cm}^{3}\right)$ ) (Bangi et al., 2008; Gao et al., 2010a; Hilonga et al., 2009; Li and Wang, 2008; Ubeyitogullari and Ciftci, 2016).

\section{CONCLUSION}

Silica aerogel was synthesized with the utilization of low-cost precursor. With the incorporation of PEG and $\mathrm{CB}$ into the silica network, PEG/silica and $\mathrm{CB} /$ silica aerogel composites were successfully prepared. Amorphous structure of the composites was revealed by XRD analyses. Mesoporous structure of the composites was shown with $\mathrm{N}_{2}$ adsorption-desorption measurements and morphological characterization. Textural properties of the silica aerogel were improved in the presence of PEG and CB. According to TGA results, highest thermal stability was belonged to $\mathrm{CB} /$ silica aerogel composite. Thermal conductivity and bulk density of the composites were slightly higher than that of the silica aerogel that not makes the composites unfavorable materials. The composites still had advantages when compared to many silica aerogels synthesized from conventional silicon alkoxides, organic/inorganic waste, industrial by-products, and so on. The results show that low-cost silica aerogel composites with promising characteristics can find many application fields to be used such as gas capture, adsorption/absorption processes, sensors, drug delivery, antibacterial applications, etc. 


\section{ACKNOWLEDGEMENT}

The authors gratefully acknowledge TUBITAK for 2211-E Direct PhD Scholarship Program, Academic Staff Training Program (2016-ÖYP-071) and Konya Technical University.

\section{REFERENCES}

Abdul Halim, Z. A., Mat Yajid, M. A., Idris, M. H., Hamdan, H., 2017, "Effects of silica aerogel particle sizes on the thermal-mechanical properties of silica aerogel - unsaturated polyester composites", Plastics, Rubber and Composites, 46, 184-192.

Acosta-Rangel, A., Sánchez-Polo, M., Polo, A. M. S., Rivera-Utrilla, J., Berber-Mendoza, M. S., 2018, "Tinidazole degradation assisted by solar radiation and iron-doped silica xerogels", Chemical Engineering Journal, 344, 21-33.

Aegerter, M. A., Leventis, N., Koebel, M. M., 2011, "Aerogels Handbook", Springer, London, 118-119.

Affandi, S., Setyawan, H., Winardi, S., Purwanto, A., Balgis, R., 2009, "A facile method for production of high-purity silica xerogels from bagasse ash", Advanced Powder Technology, 20, 468-472.

Al-Oweini, R., El-Rassy, H., 2009, "Synthesis and characterization by FTIR spectroscopy of silica aerogels prepared using several $\mathrm{Si}(\mathrm{OR})_{4}$ and $\mathrm{R}^{\prime \prime} \mathrm{Si}\left(\mathrm{OR}^{\prime}\right)_{3}$ precursors", Journal of Molecular Structure, 919, 140-145.

Alothman, Z., 2012, "A Review: Fundamental Aspects of Silicate Mesoporous Materials", Materials, 5, 2874-2902.

Aravind, P. R., Shajesh, P., Soraru, G. D., Warrier, K. G. K., 2010, "Ambient pressure drying: a successful approach for the preparation of silica and silica based mixed oxide aerogels", Journal of Sol-Gel Science and Technology, 54, 105-117.

Bangi, U. K., Venkateswara Rao, A., Parvathy Rao, A., 2008, "A new route for preparation of sodiumsilicate-based hydrophobic silica aerogels via ambient-pressure drying", Science and Technology of Advanced Materials, 9, 035006.

Casula, M. F., Corrias, A., Paschina, G., 2011, "Nickel oxide-silica and nickel-silica aerogel and xerogel nanocomposite materials", Journal of Materials Research, 15, 2187-2194.

Choi, H., Parale, V. G., Kim, T., Choi, Y.-S., Tae, J., Park, H.-H., 2020, "Structural and mechanical properties of hybrid silica aerogel formed using triethoxy(1-phenylethenyl)silane", Microporous and Mesoporous Materials, 298, 110092.

Durães, L., Maia, A., Portugal, A., 2015, "Effect of additives on the properties of silica based aerogels synthesized from methyltrimethoxysilane (MTMS)", The Journal of Supercritical Fluids, 106, 85-92.

Durães, L., Ochoa, M., Rocha, N., Patrício, R., Duarte, N., Redondo, V., et al., 2012, "Effect of the Drying Conditions on the Microstructure of Silica Based Xerogels and Aerogels", Journal of Nanoscience and Nanotechnology, 12, 6828-6834.

Gao, G.-M., Liu, D.-R., Zou, H.-F., Zou, L.-C., Gan, S.-C., 2010a, "Preparation of silica aerogel from oil shale ash by fluidized bed drying", Powder Technology, 197, 283-287.

Gao, G.-M., Xu, X.-C., Zou, H.-F., Ji, G.-J., Gan, S.-C., 2010b, "Microstructural and physical properties of silica aerogels based on oil shale ash", Powder Technology, 202, 137-142.

Ge, D., Yang, L., Li, Y., Zhao, J., 2009, "Hydrophobic and thermal insulation properties of silica aerogel/epoxy composite", Journal of Non-Crystalline Solids, 355, 2610-2615.

Goksu, E. I., Hoopes, M. I., Nellis, B. A., Xing, C., Faller, R., Frank, C. W., et al., 2010, "Silica xerogel/aerogel-supported lipid bilayers: consequences of surface corrugation", Biochimica et Biophysica Acta, 1798, 719-29.

Gurav, J. L., Jung, I.-K., Park, H.-H., Kang, E. S., Nadargi, D. Y., 2010, "Silica Aerogel: Synthesis and Applications", Journal of Nanomaterials, 2010, 1-11.

Guzel Kaya, G., Deveci, H., 2020a, "Effect of Aging Solvents on Physicochemical and Thermal Properties of Silica Xerogels Derived from Steel Slag", ChemistrySelect, 5, 1586-1591. 
Guzel Kaya, G., Deveci, H., 2020b, "Synergistic effects of silica aerogels/xerogels on properties of polymer composites: A review", Journal of Industrial and Engineering Chemistry, 89, 13-27.

Guzel Kaya, G., Yilmaz, E., Deveci, H., 2020, "Synthesis of sustainable silica xerogels/aerogels using inexpensive steel slag and bean pod ash: A comparison study", Advanced Powder Technology, 31, 926-936.

Hernandez-Campos, M., Polo, A. M. S., Sanchez-Polo, M., Rivera-Utrilla, J., Berber-Mendoza, M. S., Andrade-Espinosa, G., et al., 2018, "Lanthanum-doped silica xerogels for the removal of fluorides from waters", Journal of Environmental Management, 213, 549-554.

Hilonga, A., Kim, J.-K., Sarawade, P. B., Kim, H. T., 2009, "Low-density TEOS-based silica aerogels prepared at ambient pressure using isopropanol as the preparative solvent", Journal of Alloys and Compounds, 487, 744-750.

Hu, W., Li, M., Chen, W., Zhang, N., Li, B., Wang, M., et al., 2016, "Preparation of hydrophobic silica aerogel with kaolin dried at ambient pressure", Colloids and Surfaces A: Physicochemical and Engineering Aspects, 501, 83-91.

Ilhan, F., Fabrizio, E. F., McCorkle, L., Scheiman, D. A., Dass, A., Palczer, A., et al., 2006, "Hydrophobic monolithic aerogels by nanocasting polystyrene on amine-modified silica", Journal of Materials Chemistry, 16, 3046.

Iswar, S., Malfait, W. J., Balog, S., Winnefeld, F., Lattuada, M., Koebel, M. M., 2017, "Effect of aging on silica aerogel properties", Microporous and Mesoporous Materials, 241, 293-302.

Jaiboon, V., Yoosuk, B., Prasassarakich, P., 2014, "Amine modified silica xerogel for $\mathrm{H}_{2} \mathrm{~S}$ removal at low temperature", Fuel Processing Technology, 128, 276-282.

Jain, A., Rogojevic, S., Ponoth, S., Gill, W. N., Plawsky, J. L., Simonyi, E., et al., 2002, "Processing dependent thermal conductivity of nanoporous silica xerogel films", Journal of Applied Physics, 91, 3275-3281.

Kim, H. M., Noh, Y. J., Yu, J., Kim, S. Y., Youn, J. R., 2015, "Silica aerogel/polyvinyl alcohol (PVA) insulation composites with preserved aerogel pores using interfaces between the superhydrophobic aerogel and hydrophilic PVA solution", Composites Part A: Applied Science and Manufacturing, 75, 39-45.

Krishnaswamy, S., Tinsley, L., Marchante, V., Addepalli, S., Huang, Z., Abhyankar, H., 2017, "Effect of extrusion and compression moulding on the thermal properties of nylon-6/silica aerogel composites", Journal of Thermoplastic Composite Materials, 31, 992-1009.

Krylova, G. V., Gnatyuk, Y. I., Smirnova, N. P., Eremenko, A. M., Gun’ko, V. M., 2009, "Ag nanoparticles deposited onto silica, titania, and zirconia mesoporous films synthesized by sol-gel template method", Journal of Sol-Gel Science and Technology, 50, 216-228.

Lei, Y., Chen, X., Hu, Z., Song, H., Cao, B., 2017a, "A general strategy for improving the thermal insulation performance of aerogels by multiple impregnation", Scripta Materialia, 139, 5-8.

Lei, Y., Hu, Z., Cao, B., Chen, X., Song, H., 2017b, "Enhancements of thermal insulation and mechanical property of silica aerogel monoliths by mixing graphene oxide", Materials Chemistry and Physics, 187, 183-190.

Li, T., Wang, T., 2008, "Preparation of silica aerogel from rice hull ash by drying at atmospheric pressure", Materials Chemistry and Physics, 112, 398-401.

Liu, H., Chu, P., Li, H., Zhang, H., Li, J., 2016, "Novel three-dimensional halloysite nanotubes/silica composite aerogels with enhanced mechanical strength and low thermal conductivity prepared at ambient pressure", Journal of Sol-Gel Science and Technology, 80, 651-659.

Liu, P., Gao, H., Chen, X., Chen, D., Lv, J., Han, M., et al., 2020, "In situ one-step construction of monolithic silica aerogel-based composite phase change materials for thermal protection", Composites Part B: Engineering, 195, 108072.

Maleki, H., Durães, L., García-González, C. A., del Gaudio, P., Portugal, A., Mahmoudi, M., 2016, "Synthesis and biomedical applications of aerogels: Possibilities and challenges", Advances in Colloid and Interface Science, 236, 1-27. 
Mo, C. M., Li, Y. H., Liu, Y. S., Zhang, Y., Zhang, L. D., 1998, "Enhancement effect of photoluminescence in assemblies of nano-ZnO particles/silica aerogels", Journal of Applied Physics, 83, 4389-4391.

Nazeran, N., Moghaddas, J., 2017, "Synthesis and characterization of silica aerogel reinforced rigid polyurethane foam for thermal insulation application", Journal of Non-Crystalline Solids, 461, 1-11.

Nazriati, N., Setyawan, H., Affandi, S., Yuwana, M., Winardi, S., 2014, "Using bagasse ash as a silica source when preparing silica aerogels via ambient pressure drying", Journal of Non-Crystalline Solids, 400, 6-11.

Perego, C., Millini, R., 2013, "Porous materials in catalysis: challenges for mesoporous materials", Chemical Society Reviews, 42, 3956-76.

Pisal, A. A., Rao, A. V., 2016, "Comparative studies on the physical properties of TEOS, TMOS and $\mathrm{Na}_{2} \mathrm{SiO}_{3}$ based silica aerogels by ambient pressure drying method", Journal of Porous Materials, 23, 1547-1556.

Popovici, M., Gich, M., Roig, A., Casas, L., Molins, E., Savii, C., et al., 2004, "Ultraporous Single Phase Iron Oxide-Silica Nanostructured Aerogels from Ferrous Precursors", Langmuir, 20, 1425-1429.

Rezaei, S., Zolali, A. M., Jalali, A., Park, C. B., 2020, "Novel and simple design of nanostructured, superinsulative and flexible hybrid silica aerogel with a new macromolecular polyether-based precursor", Journal of Colloid and Interface Science, 561, 890-901.

Sachithanadam, M., Chandrakant Joshi, S., 2016, "Silica Aerogel Composites", Springer, Singapore, 15-17.

Shi, F., Liu, J.-X., Song, K., Wang, Z.-Y., 2010, "Cost-effective synthesis of silica aerogels from fly ash via ambient pressure drying", Journal of Non-Crystalline Solids, 356, 2241-2246.

Suchithra, P. S., Vazhayal, L., Peer Mohamed, A., Ananthakumar, S., 2012, "Mesoporous organicinorganic hybrid aerogels through ultrasonic assisted sol-gel intercalation of silica-PEG in bentonite for effective removal of dyes, volatile organic pollutants and petroleum products from aqueous solution", Chemical Engineering Journal, 200-202, 589-600.

Talebi, Z., Soltani, P., Habibi, N., Latifi, F., 2019, "Silica aerogel/polyester blankets for efficient sound absorption in buildings", Construction and Building Materials, 220, 76-89.

Ubeyitogullari, A., Ciftci, O. N., 2016, "Formation of nanoporous aerogels from wheat starch", Carbohydrate Polymers, 147, 125-32.

Wu, W., Wang, K., Zhan, M.-S., 2012, "Preparation and Performance of Polyimide-Reinforced Clay Aerogel Composites", Industrial \& Engineering Chemistry Research, 51, 12821-12826.

Zhang, J., Wang, J., Yang, C., Jia, H., Cui, X., Zhao, S., et al., 2017, "Mesoporous $\mathrm{SiO}_{2} / \mathrm{VO}_{2}$ double-layer thermochromic coating with improved visible transmittance for smart window", Solar Energy Materials and Solar Cells, 162, 134-141.

Zhao, J.-J., Duan, Y.-Y., Wang, X.-D., Zhang, X.-R., Han, Y.-H., Gao, Y.-B., et al., 2013, "Optical and radiative properties of infrared opacifier particles loaded in silica aerogels for high temperature thermal insulation", International Journal of Thermal Sciences, 70, 54-64.

Zhu, J., Xie, J., Lü, X., Jiang, D., 2009, "Synthesis and characterization of superhydrophobic silica and silica/titania aerogels by sol-gel method at ambient pressure", Colloids and Surfaces A: Physicochemical and Engineering Aspects, 342, 97-101.

Zinzi, M., Rossi, G., Anderson, A. M., Carroll, M. K., Moretti, E., Buratti, C., 2019, "Optical and visual experimental characterization of a glazing system with monolithic silica aerogel", Solar Energy, 183, 30-39. 